\title{
Efficient energy use and storage practices within residential facilities for compliance with the nZEB criteria
}

\author{
Ion Murgescu $^{{ }^{*}}$, Lucia-Andreea El-Leathey ${ }^{1}$, Rareș-Andrei Chihaia ${ }^{1}$, and Gabriela Cîrciumaru ${ }^{1}$ \\ ${ }^{1}$ National Institute for R\&D in Electrical Engineering ICPE-CA, Department of Efficiency in Energy Conversion \\ and Consumption, 313 Splaiul Unirii, Bucharest, Romania
}

\begin{abstract}
Solar energy, today, is the leader in renewable energy and the world's increasing new energy source. In 2016, for the first time, newly installed photovoltaic capacity has increased by more than $50 \%$, exceeding the new coal-fired power stations capacity established worldwide. At the beginning of the year, the European Parliament agreed the target that 35\% renewable sources by 2030 . Studies show that by 2050 approximately $45 \%$ of all the households in the EU could produce their own renewable energy and more than a third of them could be part of a renewable energy cooperative, despite the worries of the distribution companies. Furthermore, the EPBD directive (EU) - Energy Performance of Buildings pushes towards new and more performing buildings - nearly zero energy buildings (nZEB) - where energy efficiency and energy flexibility are essential to achieve the required performance targets. Nearly zero-energy buildings (NZEBs) have very high energy performance and could be achieved through the integration of renewable and decentralized energy sources, continuous grid optimization and the inclusion of increasing numbers of consumers becoming producers, so called prosumers. So far, the photovoltaic system is the single technology that can combine data from utility networks with household consumption and therefore should be considered a starting point for streamlining the electricity consumption and production which will be imposed by strict regulations.
\end{abstract}

\section{Introduction}

Energy consumption in the residential sector represents about $40 \%$ of the total energy use both in Europe and in the US $[1,2]$. Electricity used for heating and cooling in buildings have a high share of the overall energy use. Air conditioners are responsible on average for around 5\% of global electricity consumption, with a variable percentage in different country and such share is expected to grow due to the increasing refrigeration demand. The influence of heat pumps is continuously increasing. In 2015, approximately 800.000 units were sold in Europe and a trend of sales growth is expected for the next few years.

According to the European Commission, by 2030, more than $50 \mathrm{GW}$ of wind power and more than $50 \mathrm{GW}$ of solar energy could be held by energy communities, representing $17 \%$ and $21 \%$ of installed capacity, respectively. This will not be possible without the digitization of energy systems that will allow efficient energy management of distributed storage capacities, prosumer production and consumption. The power industry is in full transition with significant changes and new challenges for the energy systems. These challenges refer to the integration of renewable and decentralized energy sources, continuous grid optimization, and the inclusion of increasing numbers of consumers becoming producers, so called prosumers. So far, the photovoltaic system is the single technology that can combine data from utility networks with household consumption and therefore should be considered a starting point for streamlining the electricity consumption and production which will be imposed by strict regulations

In the new energy decarbonisation strategies, buildings are considered a resource in power systems due to the high energy flexibility they promise. Household main power consumption is based on certain loads (e.g., laundry machines and dish washers) and thermostatically controlled loads (TCL), such as heat pumps, refrigerators, and air conditioners [3]. The EPBD directive (EU) - Energy Performance of Buildings [4] pushes towards new and more performing buildings nearly zero energy buildings (nZEB) - where energy efficiency and energy flexibility are essential to achieve the required performance targets. The low amount of energy that these buildings require comes mainly from renewable sources. Buildings that can produce a surplus of energy over the year may be called "energy-plus buildings" and buildings that consume slightly more energy than they produce are called "near-zero energy buildings". Most nZEB buildings use the electrical grid for power supply and storage but some are independent of the grid. Energy can be harvested on-site through energy producing technologies like solar panel and wind turbines, while reducing the overall use of energy with highly efficient HVAC and LED lighting technologies.

\footnotetext{
* Corresponding author: ion.murgescu@icpe-ca.ro
} 
The zero-energy goal is becoming more practical as the costs of alternative energy technologies decrease and the costs of traditional fossil fuels increase. The development of modern zero-energy buildings became possible largely through the progress made in new energy and construction technologies and techniques. These include highly efficient insulating spray-foam insulation, high-efficiency solar panels, high-efficiency heat pumps and low-E triple-glazed windows. These innovations have also been significantly improved by academic research, through scientific papers and complex projects which collects precise energy performance data on traditional and experimental buildings and provides performance parameters which should be considered for the development of solutions than can increase furthermore the energy efficiency.

Given this premise, the sector of heating and cooling in buildings is promising for the application of Demand Side Management (DSM) strategies aimed at modifying the final user's electricity demand on the basis of electricity grid needs.

Energy demand management, also known as demand-side management (DSM) or demand-side response (DSR) is the modification of consumer demand for energy through various methods such as financial incentives and behavioural change through education. Usually, the goal of demand-side management is to encourage the consumer to use less energy during peak hours, or to move the time when energy is used to offpeak hours such as night-time and weekends. Peak demand management does not necessarily decrease total energy consumption, but could be expected to reduce the need for investments in networks and/or power plants for meeting peak demands. An example is the use of energy storage units to store energy during off-peak hours and discharge them during peak hours [5] [6]. DSM allows the increase of the share of renewable energy sources (RES) in the generation mix and hence the need to integrate them and adapt energy demand to their intermittent and unpredictable production. According to the European Commission, by 2030, more than $50 \mathrm{GW}$ of wind and more than $50 \mathrm{GW}$ of solar energy could be owned by energy clusters (associations) representing $17 \%$ and $21 \%$, respectively, of the installed capacity. This will not be possible without digitalization of energy.

\section{New Smart PV Solution}

All of the Smart PV devices have the ability to control the power injected into the network, beyond the consumer's connection, and manage the loading and unloading of storage capabilities. All systems are equipped with a SMART bidirectional meter that communicates with inverters and a WEB platform. When photovoltaic production drops below the consumption level, the difference is automatically taken from storage. When the battery is discharged, consumers will automatically be connected to the grid. This kind of system has remote monitoring capabilities, included in a friendly platform that permanently displays power generated by the system, consumption, energy produced, consumed and stored, etc.

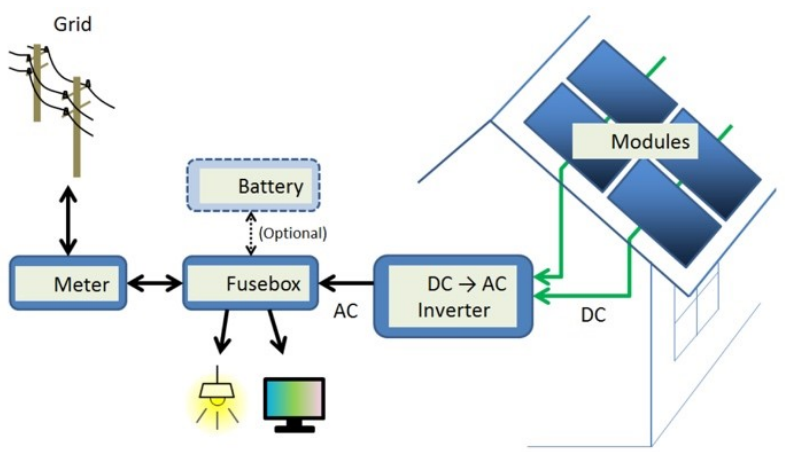

Fig. 1. Typical PV system.

There are also differences between systems. Some of these are more flexible, providing a variety of configurations and power installed or stored, but require more sophisticated installation and programming (SMA, Fronius and SolarEdge), others are plug and play but have a lower system parameter range.

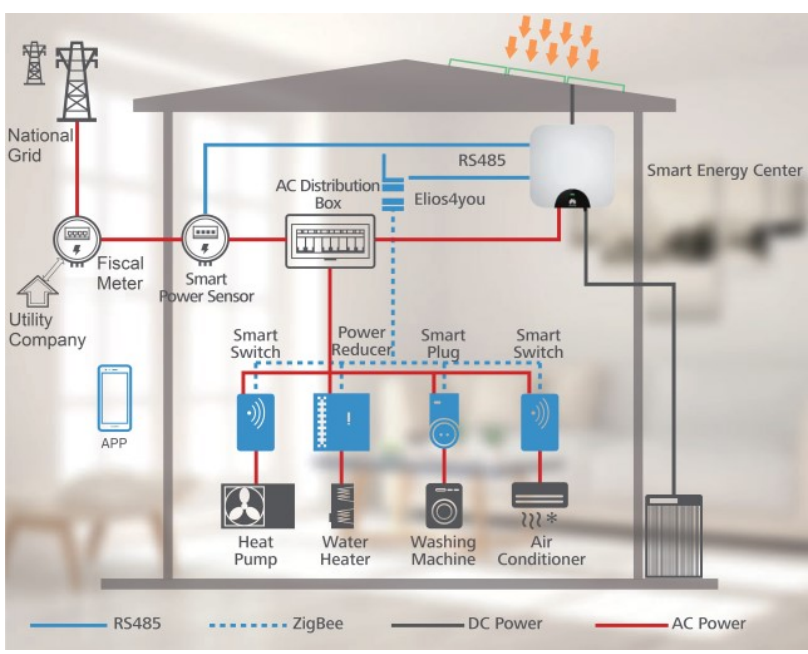

Fig. 2. SMART PV system.

The old typical PV system (fig.1) must be change with SMART PV (fig.2), that will allow digitalization and also blockchain for energy (fig.3).

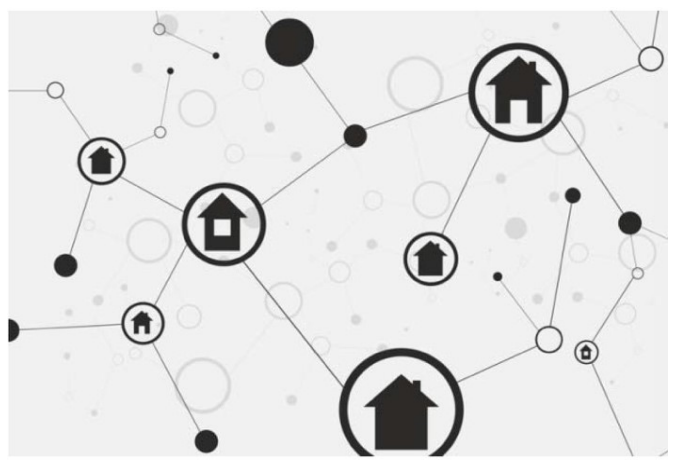

Fig. 3. Blockchain could help to facilitate peer-to-peer electricity trade within local energy communities.

The digitalization in the energy sector offers a great potential to also implement Demand Side Management 
(DSM) in residential buildings and to exploit the flexibility on the side of the consumers.

With the possibility to shift energy loads, it becomes easier to use renewable energies efficiently. The increasing number of home devices which can be controlled and the increasing number of electric cars are favorable conditions for implementing DSM, which will ensure the management of loads and storage capacities, distributed in local micro-grids. Photovoltaic, Fig.4, is the only technology that combines data from utility grids with household data and is therefore crucial to be considered in the next stage of development.

\subsection{Benefits from residential storage}

We will show as an example a simulation from UK for three typical houses, equipped with photovoltaic generators and storage batteries, [7]. The solar PV output time series are produced by the Renewables.ninja model (Pfenninger and Staffell, 2016) [8]. Renewables.ninja allows you to run simulations of the hourly power output from solar power plants located anywhere in the world. They have built this tool to help make scientific-quality weather and energy data available to a wider community. The nominal power of the generators is $12 \mathrm{~kW}$ respectively $7 \mathrm{~kW}$ and $4 \mathrm{~kW}$. Storage batteries are Li-Ion, the Powerwall 2 (named Bat 2) type, produced by Tesla. The storage capacity for each house is $13.5 \mathrm{kWh}$.

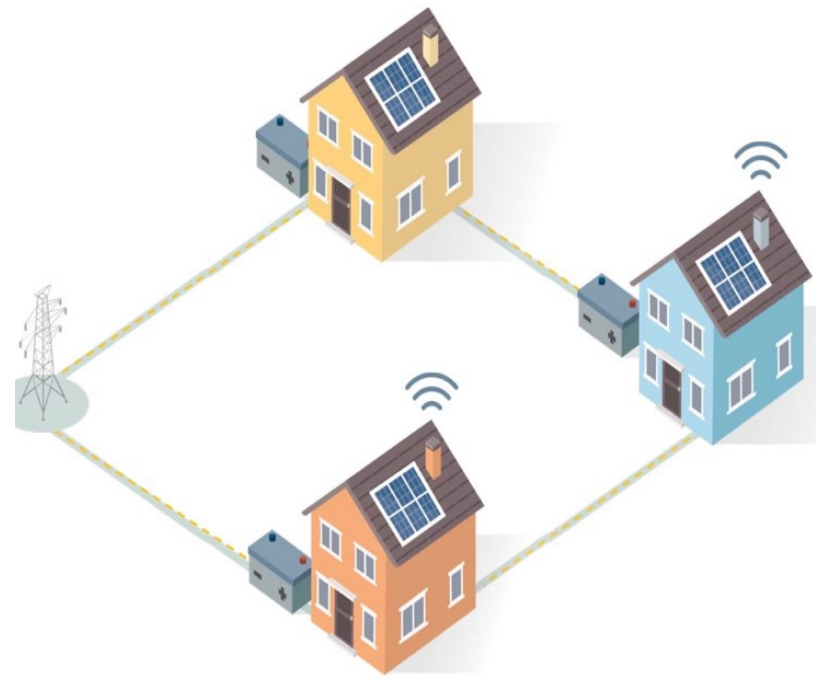

Fig. 4. SMART microgrid connected to utility grid.

For the household where the heating is not electric and the electric car is not loaded, it also simulated the energy balance for a lower capacity battery of $6.4 \mathrm{kWh}$, Powerwall type (named Bat 1). Each household's PV generators is sized to produce most of its electricity consumption, averaged over the year.

In practice, however, between a half and two-thirds of the self-generated electricity would be exported to the grid, and the current tariff system gives the consumer no benefit for the power exported. Installing the battery would allow these consumers to store between one-third and half of the power they generate, and the amount exported without payment would fall to between oneseventh and one-third of generation.
Storing $1 \mathrm{kWh}$ of power that would otherwise be lost allows it to later displace $0.9 \mathrm{kWh}$ of power from the grid, and the associated share of grid and supplier costs (including subsidies to solar panels). Adding storage to a PV system therefore significantly increases the bill savings available, without changing the payments received under the current feed-in tariff rules.

Table 1. Benefits from residential storage. Example for current UK tariff system, 2030 simulation.

\begin{tabular}{|c|c|c|c|c|}
\hline \multirow{2}{*}{$\begin{array}{l}\text { A house } \\
\text { with: }\end{array}$} & \multirow{2}{*}{$\begin{array}{c}\begin{array}{c}\text { Electric } \\
\text { Heating }\end{array} \\
\text { Bat } 2 \\
\end{array}$} & \multirow{2}{*}{$\begin{array}{c}\begin{array}{c}\text { Electric } \\
\text { Vehicle }\end{array} \\
\text { Bat } 2 \\
\end{array}$} & \multicolumn{2}{|c|}{ Neither } \\
\hline & & & Bat 2 & Bat 1 \\
\hline $\begin{array}{c}\text { Annual } \\
\text { Consumpti } \\
\text { on }(\mathrm{kWh})\end{array}$ & 10084 & 6401 & 3794 & 3794 \\
\hline $\begin{array}{l}\text { Solar PV } \\
\text { capacity } \\
(\mathrm{kW})\end{array}$ & 12 & 7 & 4 & 4 \\
\hline $\begin{array}{c}\text { Solar PV } \\
\text { output } \\
(\mathrm{kWh}) \\
\end{array}$ & 9767 & 5697 & 3256 & 3256 \\
\hline $\begin{array}{l}\text { Exports } \\
\text { without } \\
\text { storage } \\
(\mathrm{kWh})\end{array}$ & $\begin{array}{c}6474 \\
(66 \%)\end{array}$ & $\begin{array}{c}3789 \\
(67 \%)\end{array}$ & $\begin{array}{c}1842 \\
(57 \%)\end{array}$ & $\begin{array}{c}1842 \\
(57 \%)\end{array}$ \\
\hline $\begin{array}{l}\text { Storage } \\
\text { capacity } \\
(\mathrm{kWh})\end{array}$ & 13.5 & 13.5 & 13.5 & 6.4 \\
\hline $\begin{array}{c}\text { Energy } \\
\text { stored } \\
(\mathrm{kWh} / \text { yea })\end{array}$ & $\begin{array}{l}3205 \\
(33 \%)\end{array}$ & $\begin{array}{c}2884 \\
(51 \%)\end{array}$ & $\begin{array}{c}1386 \\
(43 \%)\end{array}$ & $\begin{array}{c}1376 \\
(42 \%)\end{array}$ \\
\hline $\begin{array}{l}\text { Exports } \\
\text { after } \\
\text { storage } \\
(\mathrm{kWh})\end{array}$ & $\begin{array}{c}3269 \\
(33 \%)\end{array}$ & $\begin{array}{c}905 \\
(16 \%)\end{array}$ & $\begin{array}{c}456 \\
(14 \%)\end{array}$ & $\begin{array}{c}465 \\
(14 \%)\end{array}$ \\
\hline $\begin{array}{l}\text { Electricity } \\
\text { bill before } \\
\text { PV (£/year) }\end{array}$ & 1405 & 892 & 529 & 529 \\
\hline $\begin{array}{c}\text { Electricity } \\
\text { bill after } \\
\text { PV (£/year) }\end{array}$ & 946 & 626 & 332 & 332 \\
\hline $\begin{array}{c}\text { Electricity } \\
\text { bill after } \\
\text { PV and } \\
\text { storage } \\
\text { (£/year) } \\
\end{array}$ & 544 & 264 & 158 & 159 \\
\hline $\begin{array}{l}\text { Saving due } \\
\text { to storage } \\
\text { (£/year) }\end{array}$ & 402 & 362 & 174 & 173 \\
\hline
\end{tabular}

The right-hand columns of Table 1 show that for a home with neither electric heating nor an electric vehicle, there is little difference between the two storage versions. The smaller Bat 1 only needs to export an additional $10 \mathrm{kWh}$, cycling between empty and full three times over the year, compared to the single cycle of the Bat 2. The smaller systems would be able to deliver high proportions of the bill savings from the full-sized Bat 1 . The gross savings are greatest for a household with electric heating, and flatten off with the largest amount of storage capacity, at about $18 \mathrm{kWh}$. A household with an electric vehicle has very similar savings up to a capacity of $11 \mathrm{kWh}$, but has exhausted its savings from that point onwards. 
The low-consumption household with neither electric heating nor a vehicle needs no more than $5 \mathrm{kWh}$ to use almost all of its arbitrage potential. It should not be surprising to see that for any capacity of storage this household has the lowest gross savings.

While it is straightforward to show that relatively small storage systems can still obtain a high proportion of the gross bill savings available from a full-scale Powerwall, and the cost of the battery cells should be almost proportional to the storage capacity, there are also fixed costs such as inverters and installation. Tesla's installation charge of $£ 950$ implies a ten-year annuity of over $£ 120$ per year needs to be earned back (with a $5 \%$ discount rate), before paying for the battery, which would tend to make small systems uneconomic.

An obvious technical solution would be to pool several residences together, e.g. the houses on a street or the flats in a block. Ten houses would gain much greater benefits from a single Powerwall than a single household.

\subsection{Smart PV Solution available on the market}

As expected, the industry has responded promptly, and manufacturers have prepared early on SMART equipment with embedded storage systems and power management software that adapts to both consumer and network types. Fronius, Huawei, SolarEdge, SMA, Delta, Imeon, Growatt and other, have launched intelligent energy storage and hybrid systems (ongrid and offgrid).

FRONIUS has launched the range of three-phase SYMO Hybrid inverters and storage batteries with the Fronius Solar Battery integrated controller within the 24 hour of sun program. SYMO Hybrid is available in three versions.

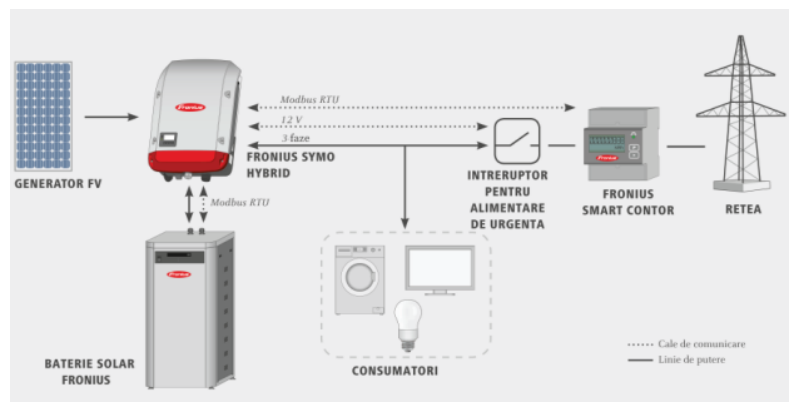

Fig. 5. FRONIUS system.

The Fronius Battery System is available in six versions with usable capacity $(80 \% \mathrm{DoD})$ of $3.6 \mathrm{kWh}$, $4.8 \mathrm{kWh}, 6.0 \mathrm{kWh}, 7.2 \mathrm{kWh}, 8.4 \mathrm{kWh}$ and $9.6 \mathrm{kWh}$. The warranty provided by Fronius for battery systems is 15 years. At INTERSOLAR fair in Munich, Fronius announces the launch of a new equipment, Fronius Ohmpilot, which increases the rate of use of solar energy for its own consumption by heating the water and another simpler energy storage solution. Also, a cloudbased software program on its own web platform will be available to optimize its own consumption based on weather data and data automatically acquired from the system.
HUAWEI, launched in 2017 the Fusion Home Smart Energy Solution, a SMART residential system that delivers energy-saving, low-cost design with relatively small dimensions $(375 \times 375 \times 117) \mathrm{mm}$, weighing only $10.6 \mathrm{~kg}$ and which can be plug and play by a single person. It is a single-phase system with powers from $2 \mathrm{~kW}$ to $5 \mathrm{~kW}$ a.c.

The new system is equipped with power optimizers mounted on photovoltaic panels that communicate wireless with the central unit. Optimizers bring a 5\% production increase due to extra gain at sunrise and sunset, up to $30 \%$ where the roof is complex with differently oriented surfaces. The system also communicates with the cloud, allowing optimization of consumption for different types of residential consumers.

The SolarEdge residential solution integrates photovoltaic energy production with battery storage and SMART (power grid, stored energy, consumer energy management and power optimization control) functions under the control of a single PV SolarEdge inverter. The SolarEdge DC-optimized system offers substantial benefits, including higher photovoltaic power, better system state supervision and advanced security features.

\section{Optimizing Self-Consumption + Backup Power}

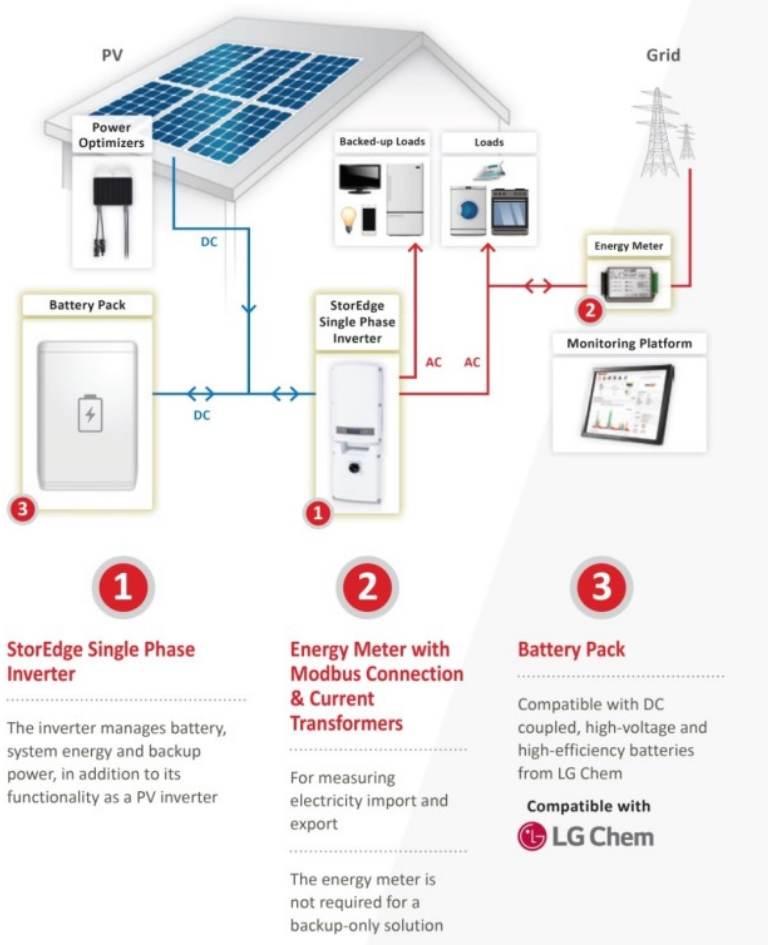

Fig. 6. SolarEdge system.

The SMART SolarEdge system uses surplus energy production for heating water in heat pumps, hot water boilers, lighting, or other household appliances. Homeowners easily benefit from smart device control through the SolarEdge mobile monitoring application.

SMA, one of the first manufacturers to introduce digitization into residential PV systems, offers a lot of flexibility in designing residential systems covering a wide range of smart power and intelligent management capabilities of photovoltaic power generation and home 
load (wired) by Sunny Home Manager and RadioControlled Sockets, all integrated into SMA SMART HOME, with the slogan: The System Solution for Greater Independence.

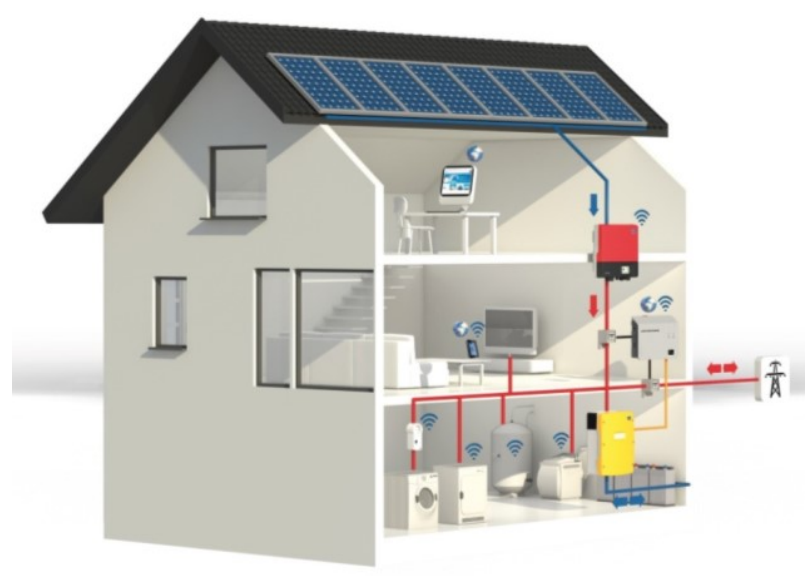

Fig. 7. SMA system.

Intelligent energy management begins with the recording and assessment of household energy flows. This energy monitoring analyzes both total energy consumption and individual appliances using the radiocontrolled socket measurement function. Based on the information compiled in this way, Sunny Home Manager creates an overview of different views and charts from Sunny Portal (SMA platform). The user can use this overview to understand the energy flows in his household and can decide in which areas it deserves to implement intelligent energy management. The Sunny Home Manager also provides recommendations on when the user can switch to specific devices to significantly increase their own consumption. The next step is active energy management through automatic load control. With the on / off switch of the radio-controlled or data cable connection; the tasks can be started by the Sunny Home Manager exactly when the PV system generates sufficient power or when the energy costs are particularly low.

\section{The prospect of developing smart PV systems in Romania}

In 2017, the European Commission published a study regarding "Residential Prosumers in the European Energy Union", which shows that up to now, Romania has not encouraged the development of residential prosumers, but there is a premise that an energy policy in this respect will be implemented by 2030 . Until 2018, all governments that administered Romania did not provide any support or facilities for installing renewable electricity generators on residential buildings. As a result of this policy, Romania ranks first in Europe in terms of the ratio between the total installed capacity for utilities and the capacity installed on the roofs (Fig.7). In 2018 Romania have connected at SEN (National Energy System) 1375 MW total photovoltaic power but only 13.3MW are residential PV installations, (less than $1 \%$ of the total). It is the smallest percentage in the European Union.

The new Law no. 184/2018 for the approval of Government Emergency Ordinance no. 24/2017 regarding the amendment and completion of the Law no. $220 / 2008$ establishing the system for promoting the production of energy from renewable energy sources and amending some normative acts, has introduced, for the first time in Romanian legislation, the definition of prosumer. The prosumer is the final client that owns power-generating installations of maximum $27 \mathrm{~kW}$ installed power, including cogeneration, and which consumes and can store and sell electricity produced in their own building, including a block of flats, residential site or business, provided these activities do not constitute their primary commercial or professional activity. The prosumers are exempted from obtaining authorizations or from paying taxes on the energy.

Another support, for PV residentials area, came from the Environment Ministry, which will allocate 100 million euros through the Environment Fund to relaunch the Green House program in October. Through this program, 26,000 households will be able to benefit from photovoltaic modules for electricity production monitored by the Environmental Fund Administration (AFM). AFM has imposed technical and performance conditions for photovoltaic equipment so that at the end of the program, Romania will have around 26,000 stateof-the-art facilities that will produce and share their own energy. The PV installations will have smart residential inverter that will communicate with smart meter, will manage the energy and will communicate wits cloud, on different program, to get maximum energy efficiency.

Romania, according to the mentioned survey and based on Eurostat data, owns 7.470 .000 private houses (excluding apartment blocks and rental houses) with a total area of $205 \mathrm{Km}^{2}$. Of these, $60 \%$ have the potential to become autonomous by installing photovoltaic roof panels, reaching up to 3.36 million photovoltaic installations and an installed power of 5900MW.

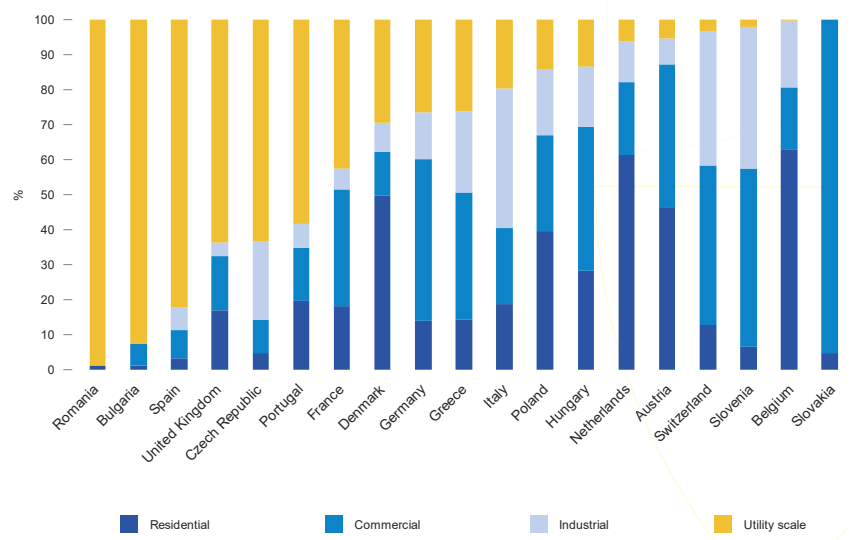

Fig. 8. - European solar PV total capacity until 2017 for selected countries

The chart is relevant to Romania's renewable energy policy. The defining characteristics of countries with low absorption rates (low number of prosumers) in relation to 
the technical potential, according to the study, are the following:

- Low levels of sunlight make electricity generation so low over a year that the investment is not feasible, as is the case for Ireland and Finland. This is not the case for Romania, which has an insolation greater than Germany, the country with the highest number of residential pros and cons;

- Policy is less favorable to the development of photovoltaic energy, as is the case with Romania;

- Existence of large barriers to investment. No Romanian bank funds for the moment investments in residential photovoltaic generators.

The European Parliament, approved in January 2018, mandatory targets at EU level to improve energy efficiency by $35 \%$ and a minimum $35 \%$ share of gross final consumption of energy from renewable sources. Member States are also required to assess existing barriers to their own energy consumption (produced at the consumer's household - prosumer), to promote such consumption and to ensure that all consumers, especially households, can join renewable energy communities locally, without being subject to unjustified conditions or complicated procedures.

Parliament wants to make sure that consumers have the right to consume the energy they produce and install storage systems without having to pay taxes. To meet these overall objectives, EU Member States need to set their own national targets, monitored and implemented in line with an Energy Efficiency regulations. For the first time, the EU recognizes a universal right for citizens to produce, store and sell renewable electricity without any surcharges, such as tariffs for network connections. However, with regard to energy democracy and the empowerment of citizens and private entities, the Commission seems more ambitious than some countries. While Greece, Belgium and Hungary have expressed their support for the citizens' energy policy, Spain and Germany, supported by France and Britain, seem to oppose.

According to the European Commission, by 2030, more than $50 \mathrm{GW}$ of wind and more than $50 \mathrm{GW}$ of solar energy could be held by energy communities, representing $17 \%$ and $21 \%$ of installed capacity, respectively.

This is an immense opportunity for local communities, especially in rural areas. Currently, the negotiations between the European Parliament and the Council for the Clean Energy Package are in debate, and the energy policies for citizens and the regulations for prosumers are essential.

As shown above, for the alignment with the European policy, the first steps were taken in Romania through a law which establish the frame for a promoting system of the energy production from renewable energy sources.

There are still many issues to be solved from the legislative point of view, but the key element will be to stimulate and support prosumers who can invest in nearly zero emission houses and equipment for clean energy generation.

\section{Conclusion}

Households in their new joint role as prosumers play a vital role in the transformation of the energy system in Europe. With new power generating technologies and additional equipment these households are able to change the typical known demand patterns and facilitate peak shaving of electric power. By increasing the share of renewable energy in the market, fossil fuelled power plants can be gradually pushed out of the market and $\mathrm{CO} 2$ emissions can be reduced. Beside these technical and environmental benefits of prosumer households, macroeconomic effects of prosumer households in Europe are presented.

The number of prosumer households is also expected to rise further by the promotion and/or cost decreases of batteries. Battery systems increase the attainable selfconsumption, which is attractive for prosumer households. The usable battery capacity has to be suitable for the installed solar PV systems in order to realize a high degree of self-consumption.

Self-consumption systems are only efficient with large storage capacities. The cost of storage is still high. The amount of profit available from each household is likely to be small, and transactions costs (including customer acquisition) will take some part from it.

This work was financially supported by the following grants of the Romanian Ministry of Research and Innovation (MCI): CCCDIUEFISCDI, project number PN-III-P1-1.2-PCCDI-2017-0391 / CIA_CLIM - Smart buildings adaptable to the climate change effects and also by NUCLEU 2018 Programme, project number PN18240201/ 2018 - Efficient energy conversion and storage systems for electrical engineering applications.

\section{References}

1. EIA (U.S. Energy Information Administration). Annual Energy Outlook 2018 with projections to 2050 Available online: http://www.eia.gov/tools/faqs/faq.cfm?id=86\&t=1 (accessed on 13 July 2018)

2. Arcipowska A., Rapf O., Faber M., Fabbri. M. Tigchelaar C., Boermans T., Surmeli-Anac N., Pollier K., Dal F., Sebi C., Karásek J. Support for setting up an observatory of the building stock and related policies, Service contract no. ENER/C3/2014-543 (2016)

3. Alessia Arteconi 1,* ID and Fabio Polonara ${ }^{2}$ Assessing the Demand Side Management Potential and the Energy Flexibility of Heat Pumps in Buildings (July 2018)

4. European parliament and the Council of the European Union, Directive (EU) 2018/844 of the European parliament and of the council of 30 May 2018 (New EPBD) amending Directive 2010/31/EU on the Energy Performance of Buildings and Directive 2012/27/EU on Energy Efficiency Available on site: https://ec.europa.eu/info/news/new-energyperformance-buildings-directive-comes-force-9july-2018-2018-jun-19 en 
5. Chiu Wei-Yu, Sun Hongjian, Poor H. Vincent, Browse Journals \& Magazines - IEEE Transactions on Smart Grid, Energy Imbalance Management Using a Robust Pricing Scheme 4 (2), 1484, (2013)

6. WY Chiu, H Sun, HV Poor - IEEE Third International Conference on Smart Grid Communications (SmartGridComm), Demand-side energy storage system management in smart grid 73, 78, 5-8. (2012)

7. R. Greena, I. Staffell, The Quarterly Journal of the IAEE's Energy Economics Education Foundation, "Prosumage" and the British electricity market, 6, (2017)

8. Time series for national outputs, and a tool to calculate a year's production from a panel or turbine anywhere in the world, are available at https://www.renewables.ninja 